\title{
CARDIAC EFFECTS OF ANTIDEPRESSANTS
}

\author{
E. MARMO, L. COSCIA and S. CATALDI \\ Department of Pharmacology and Toxicology, University of Naples, Italy
}

Received for publication July 28, 1971

The present study was undertaken to investigate the cardiac effects of 5 antidepressive tricyclic derivatives namely imipramine, desipramine, amitriptyline, trimeprimine and noxiptiline (Fig. 1). The following parameters were studied:

1) In vivo: Effects on $E C G$, their anti-arrhythmic and anticoronarospastic activity.

2) In vitro: Effects on the inotropism, chronotropism and coronary flow.
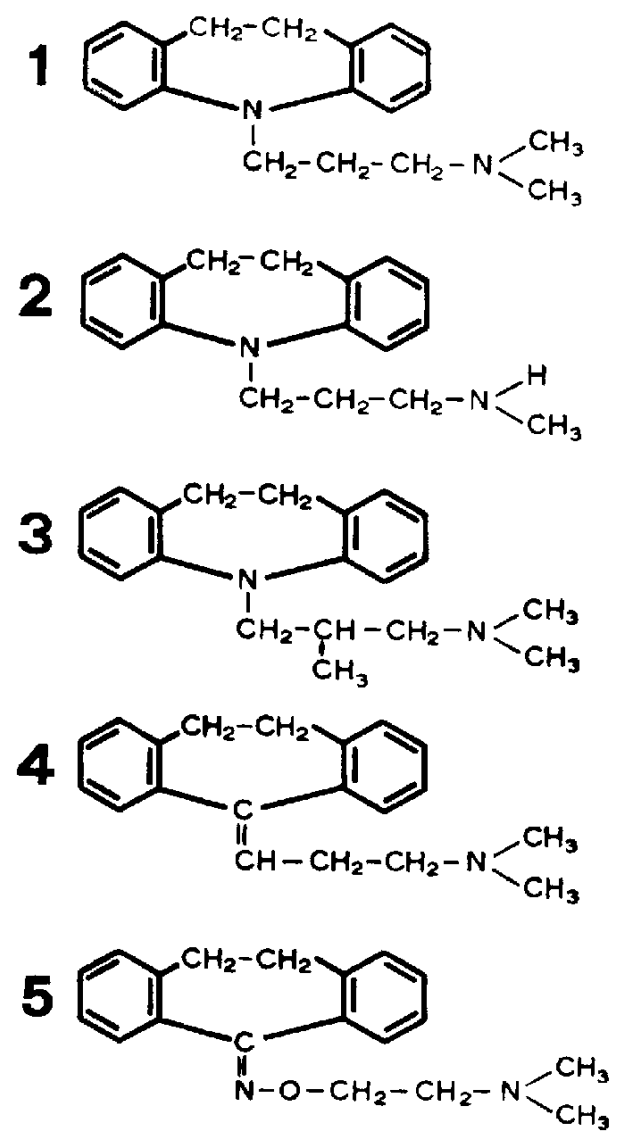

Fig. 1. Structure formulas of the tricyclic derivatives studied : imipramine (1), desipramine (2), trimeprimine (3), amitriptyline (4) and noxiptiline (5). 


\section{MATERIAL AND METHODS}

\section{Animals and drugs}

Adult rats of either sex weighing 130-290 g and of Morini strain were used. Guineapigs (400-500 g) were supplied locally. No pregnant animals of either species were used.

Drugs used were procainamide sulfate (Sigma); aconitine sulfate (Simes); reserpine (Ciba); $\mathrm{BaCl}_{2}$ and $\mathrm{CaCl}_{2}$ (C. Erba); K-strophantoside (Maggioni); pitressin (Parke Davis); imipramine hydrochloride and desipramine hydrochloride (Geigy); amitriptyline hydrochloride, trimeprimine malcate and noxiptiline hydrochloride (Bayer). The substances were dissolved in distilled $\mathrm{H}_{2} \mathrm{O}$.

\section{ECG studies}

Rats anaesthized with ethylurethane ( $1 \mathrm{gm} / \mathrm{Kg}$; i.p.) were immobilized on a lying bed and prepared for ECG recording on lead II. The electrocardiograph used was a Cardioline mod. Epsilon 2 (paper sliding speed $50 \mathrm{~mm} / \mathrm{sec}$; setting $1 \mathrm{mV} / \mathrm{cm}$ ). All the drugs were administered intravenously i.e., external jugular vein.

3. In vitro studies on heart

Guinea pigs were sacrificed by a blow on the neck. The beating heart was taken out immediately, mounted on Langendorff-Spadolini apparatus. It was perfused with oxygenated Ringer-Locke solution at $38^{\circ} \mathrm{C}$ with a $60 \mathrm{~cm} \mathrm{H}_{2} \mathrm{O}$ pressure at the level of the coronary ostioles. The frequency and the amplitude of the cardiac contractions as well as the coronary flow was measured as described by Marmo et al. (1). The perfusion with Ringer-Locke medicated with tricyclic derivatives was carried out for a period of $20 \mathrm{~min}$. It was preceded and followed by perfusions with normal Ringer-Locke solution for a period of $10 \mathrm{~min}$ each.

4. Studies on the anti-arrhythmic and anti-coronarospastic activity

The lethal and the ECG effects were recorded on anaesthetized rats and guinea- pigs after intravenous administration of the following drugs:

I: Rats a) $\mathrm{BaCl}_{2}$ (50 mg/ $/ \mathrm{kg} / \mathrm{min}$, i.v. up to death; $0.5 \mathrm{ml} \mathrm{liquid} / \mathrm{animal} / \mathrm{min}$ )

b) $\mathrm{CaCl}_{2}(100 \mathrm{mg} / \mathrm{kg} / \mathrm{min}$, i.v. up to death; $0.5 \mathrm{ml}$ liquid/animal $/ \mathrm{min})$

c) Aconitine $(15 / / \mathrm{g} / \mathrm{kg} / \mathrm{min}$ i.v. up to death; $0.5 \mathrm{ml}$ liquid/animal $/ \mathrm{min})$

II: Guinca-pigs a) K-strophantoside $50, \mathrm{gg} / \mathrm{kg} / \mathrm{min}$ i.v. up to death; $0.5 \mathrm{ml}$ liquid/animal/min)

b) Pitressin (1.5 I.U./kg i.v. in $10 \mathrm{sec}$ )

The animals were pretreated intravenously. One minute before administration of the toxic drugs, either with $\mathrm{NaCl} 0.9 \%(5 \mathrm{ml} / \mathrm{kg}$ in $4 \mathrm{~min})$ or with the tricyclic derivatives $(5 \mathrm{mg} / \mathrm{kg}$ in $4 \mathrm{~min} ; 5 \mathrm{ml} \mathrm{liquid} / \mathrm{kg}$ ). The ECG were recorded in lead II.

\section{RESULTS}

\section{ECG studies}

Intravenous perfusion of tricyclic derivatives (Imipramine, desipramine, trimeprimine, amitriptiline and noxiptiline) at a dose of $5 \mathrm{mg} / \mathrm{kg} / \mathrm{min}$ up to death, produced the following effects in anaesthetized rats:

a) Excitability disturbances: i.e. sinus bradycardia, sometimes preceded by a slight 
and transitory tachycardia; occasionally either an ectopic rhythm supraventricular or a nodal rhythm accompanied with supraventricular extrasystoles.

b) Conduction disturbances: Alterations in atrioventricular conduction, i.e. lengthening of PR interval atrioventricular blocks of 1st, 2nd and 3rd grade; blocks of the branch.

c) Depolarization disturbances: aspects of ventricular overload especially on the right type; the ventricular repolarization was usually very precociously disturbed, with sliding of ST and flattening or inversion of T-wave, which do not seem to be determined by ischemic lesion.

The onset of cardiotoxic and lethal effects due to i.v. perfusions of the tricyclic derivatives (cxcept amitriptylinc) was retarded in animals pre-treated for $24 \mathrm{hr}$ with reserpine at the dose of $5 \mathrm{mg} / \mathrm{kg}$, i.p. (Figs. 2-6 and Table 1 ).

2. Perfusion studies (in vitro)

Perfusion for a period of $20 \mathrm{~min}$ with the tricyclic derivatives on guinca-pig hearts beating in vitro, did not significantly modify the coronary flow, the chronotropism and the inotropism in concentrations of $10^{-9} \ldots 10^{-7}(\mathrm{~g} / \mathrm{ml})$ of noxiptiline, imipramine, desipramine, trimeprimine and amitriptyline. In the case of noxiptiline at concentrations of $10^{-6}(\mathrm{~g} / \mathrm{ml})$, a slight increase of the frequency and the amplitude of cardiac contractions was often recorded (the increase in amplitude was a consequence of an intensification of the

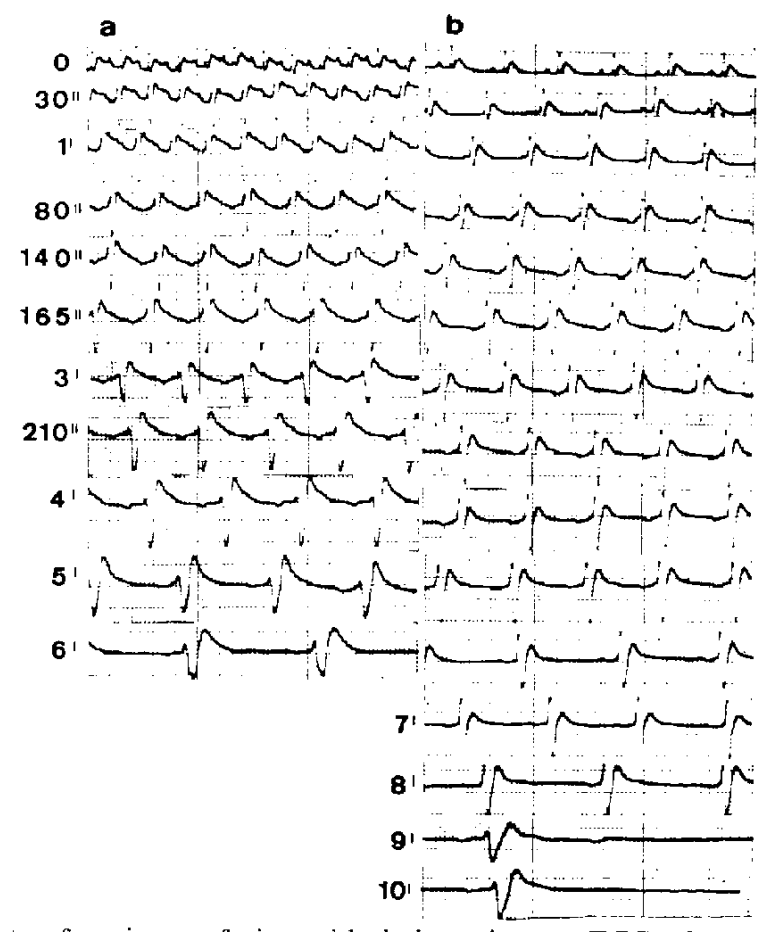

FiG. 2. Effects of an i.v. perfusion with imipramine on ECG of a normal rat (a) and a rat pre-treated for $24 \mathrm{hr}$ with reserpine (b). 0 =- basal ECG. Side numbers indicate time at which ECG was carricd out. Rats $a$ and $b$ dicd after 7 min (a) and 10 min $30 \mathrm{sec}$ (b) from the beginning of perfusion with imipramine. 


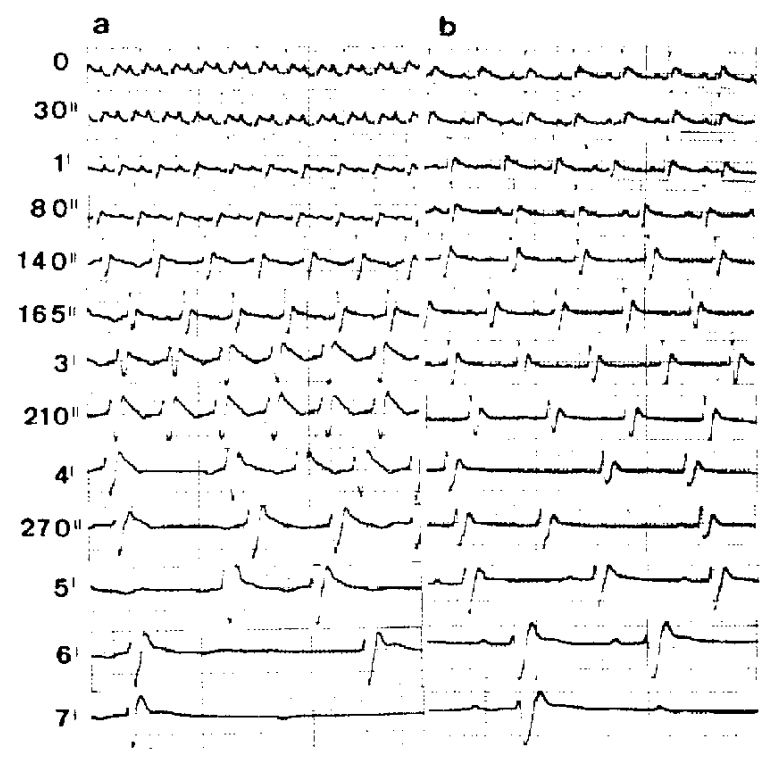

FIG. 3. Effects of an i.v. perfusion with desipramine on ECG of a normal rat (a) and a rat pre-treated for $24 \mathrm{hr}$ with reserpine (b). $0=$ basal ECG. Side numbers indicate time at which ECG was carried out. Rats $a$ and $b$ died after 7 min $30 \mathrm{sec}$ (a) and $8 \mathrm{~min} 50 \mathrm{sec}$ (b) from beginning of perfusion with desipramine.

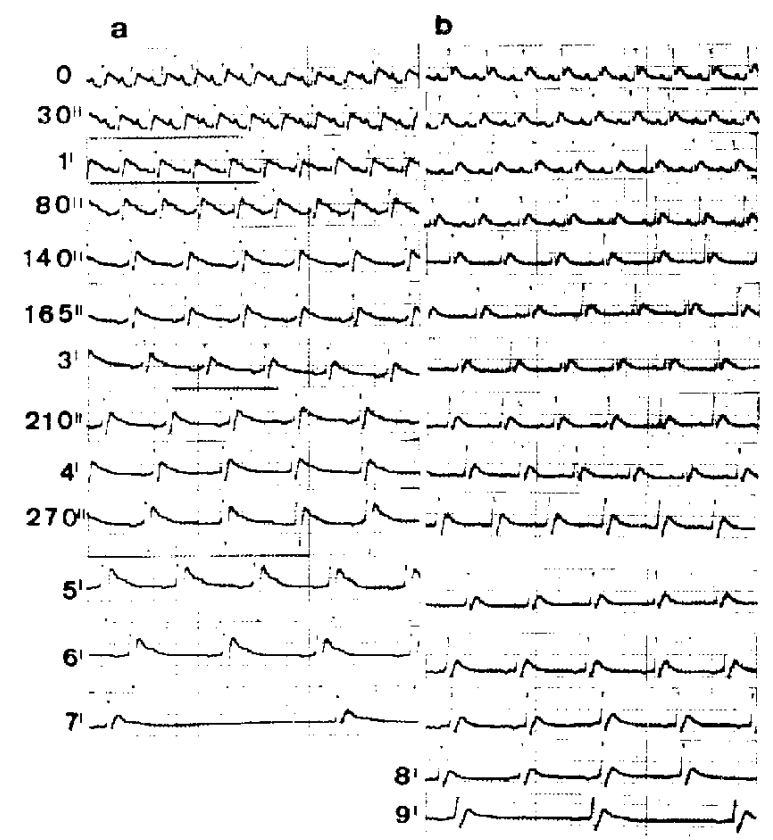

FIG. 4. Effects of an i.v, perfusion with trimeprimine on ECG of a normal rat (a) and a rat pre-treated for $24 \mathrm{hr}$ with reserpine (b). 0 -basal ECG. Side numbers indicate time at which ECG was carried out. Rats $a$ and $b$ died after 7 min 40 $\mathrm{sec}$ (a) and 11 min $50 \mathrm{sec}$ (b) from beginning of perfusion with trimeprimine. 


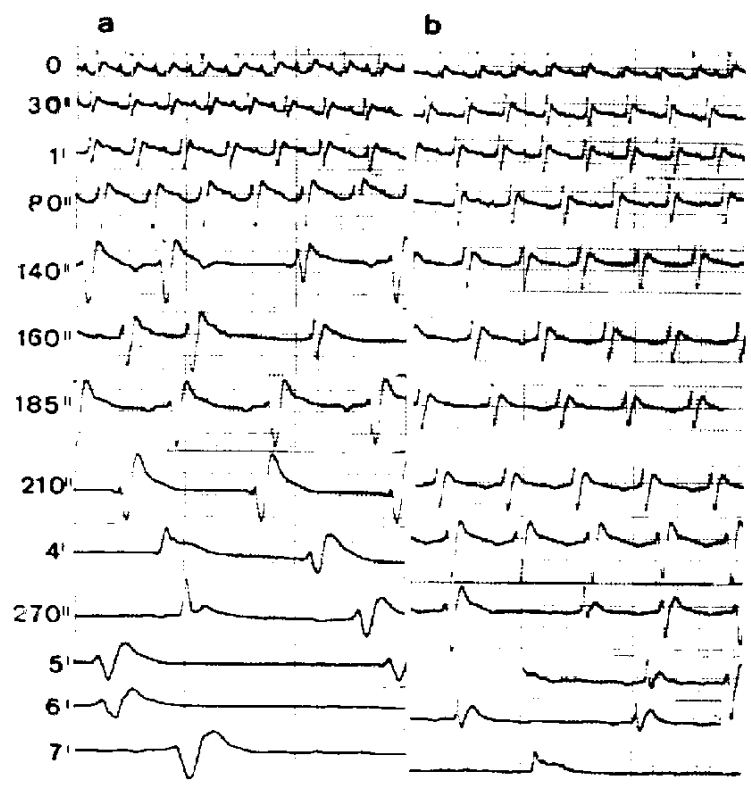

Fri. 5. Effect of an i.v. perfusion with amitriptyline on FCG of a normal rat (a) and a rat:pre-trealed for $24 \mathrm{hr}$ with rescrpine b) 0 basal ECG. Side mumbers indicate time at which ECG was carried out. Rats a and h died after 7 min $35 \mathrm{sec}$ (a) and 7 min $30 \mathrm{sec}$ (b) trom beginning of perfusion with amitriply. linc.

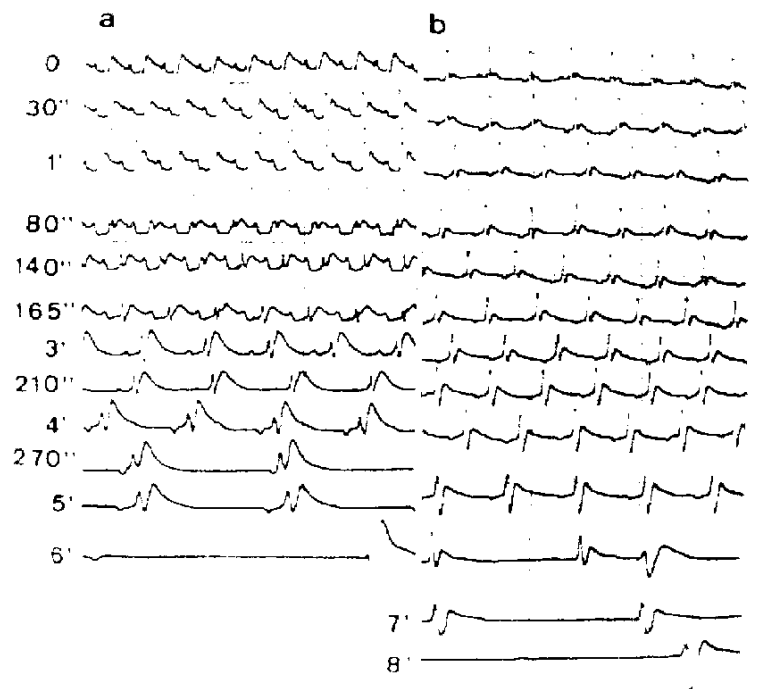

Fici. 6. Elfects of an i.y. perfusion with noxiptiline on ECG of a normal rat fa. and a rat pre-treated for 24 hr wh reserpine b). O hasal ECG. Side number indicate time at which ECG u 15 earrixd out. Ra1s a and $b$ died after 8 min (a) and 10 min $15 \mathrm{se}$ (b) from heginning of perfusion with noxipilin 
IABLt 1. Lethality caused by $i_{-}$. perfusions of different drugs ( $5 \mathrm{mg} \mathrm{kg}$ min up to death) on normal rats (a) or on rats pre-treated (b) for $24 \mathrm{hr}$ with reserpine (5mgkg i.p.).

\begin{tabular}{|c|c|c|c|}
\hline $\begin{array}{c}\text { Number of } \\
\text { animals }\end{array}$ & $\begin{array}{l}\text { Experimental } \\
\text { group }\end{array}$ & Treatment & $\begin{array}{l}\text { Survival } \\
\text { min : S.E. }\end{array}$ \\
\hline 4 & $a$ & Imipramine & $620^{\prime \prime} \cdot 49^{\prime \prime}$ \\
\hline 4 & $b$ & Imipramine & $10^{\prime} 15^{\prime \prime}-56^{\prime \prime}(*)$ \\
\hline 4 & $a$ & Desipramine & $745^{\prime \prime} \cdot 35^{\prime \prime}$ \\
\hline 4 & $b$ & Disipramine & $90 l^{\prime \prime} \cdot 38^{\prime \prime}$ \\
\hline 4 & $a$ & Trimeprimine & $725^{\prime \prime}: 54^{\prime}$ \\
\hline 4 & $b$ & Trimeprimine & $11^{\prime} 36^{\prime \prime}: 46^{\prime \prime}\left(*^{*}\right)$ \\
\hline 4 & $a$ & Amitriptyline & $7^{\prime} 40^{\prime \prime}: 42^{\prime \prime}$ \\
\hline 4 & $b$ & Amitriplyline & $730^{\prime \prime}-28^{\prime \prime}$ \\
\hline 4 & $a$ & Noxiptiline & $8^{\prime} 10^{\prime \prime}-52^{\prime \prime}$ \\
\hline 4 & $b$ & Noxiptiline & $10^{\prime} 24^{\prime \prime}+43^{\prime \prime}\left(*^{*}\right)$ \\
\hline
\end{tabular}

(*) Statistically significant values $P$ P 0.05$)$ to groups a. S.E. = standard error.

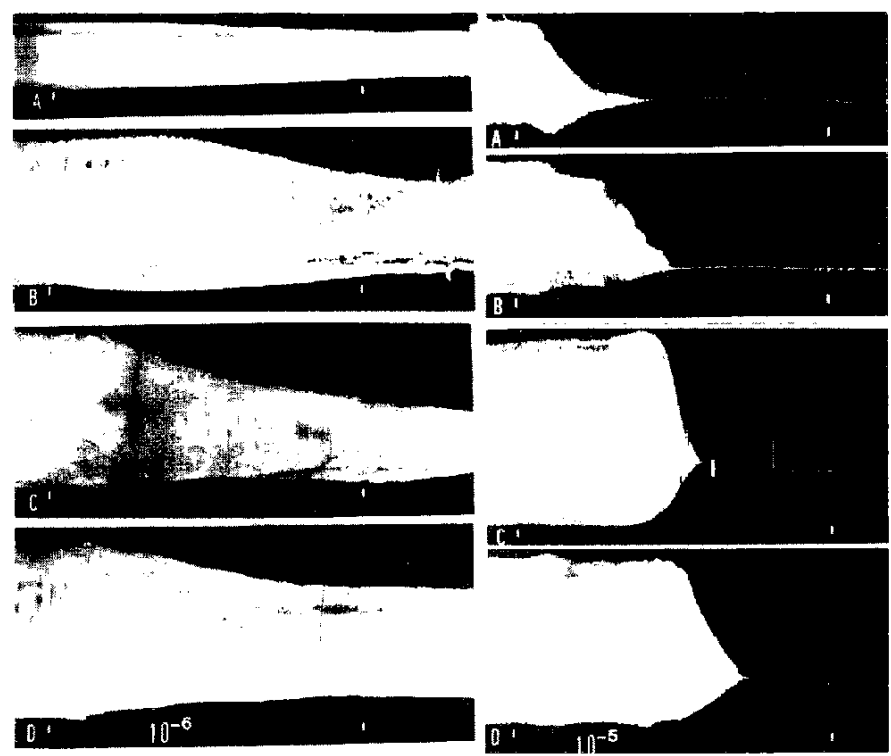

Fic. 7. Isolated hearts of 8 guinea-pigs. Between the 2 signs a perfusion (duration 20 min) of Ringer-Locke medicated with amitriptyline (A), with imipramine (B). with desipramine $(C)$ or with trimeprimine $(D)$, in concentrations of $10^{-6}$ or of $10^{-1}(\mathrm{~g} \mathrm{ml})$.

diastolic relaxation), not combined 10 significant variations of the coronary fow. At concentrations of $10^{-6}(\mathrm{~g} / \mathrm{ml})$ imipranine, desipramine, trimeprimine and amitriptiline and of $10^{-5}(\mathrm{~g} / \mathrm{ml})$ noxiptiline. all drugs significantly reduce the coronary flow, and the frequency and the amplitude of cardiac contractions (both as to systolic phase and diastolic phase) (Figs. 7, 8 and Table 2).

$\therefore$ Ant-arhyhmic and anti-coronarospastio sudies

The tricyclic derivatives fimipramine, desipramine, trimeprimine, amitriptyline and 


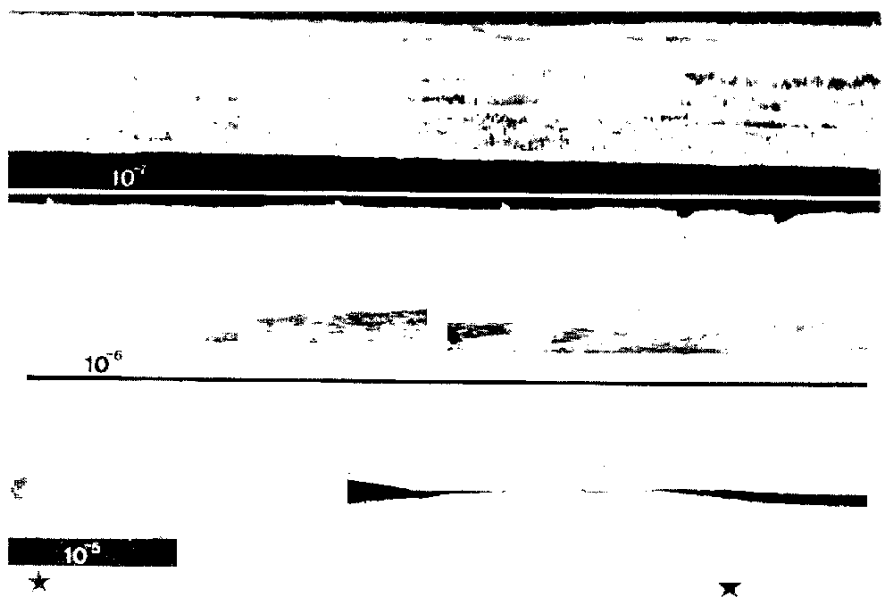

Fici. 8 Isolated heurts of 3 guinea-pigs. Between the 2 signs a perfusion duration $20 \mathrm{~min}$ ) of Ringer-Locke medicated with noxiptiline in concentrations of $10^{-i}, 10^{-r}$ or of $10^{-i}<\mathrm{g} \mathrm{ml}$.

Takbr 2. Elfects in vitro of the tricyclic derivatives on coronary flow, chronotropism and the inotropism of guinea-pig heart.

\begin{tabular}{|c|c|c|c|c|c|c|}
\hline \multirow[t]{2}{*}{ Drug } & & \multicolumn{5}{|c|}{$\begin{array}{l}\text { Percentage variations of coronary thow }(\mathrm{A}) \text { of chronotropism } \mathrm{B} \text { ) } \\
\text { and of inotropism C compared to the values of controls aftcr } 20 \\
\text { min perfusions with the following concentrations (g ml) of the } \\
\text { drugs }\end{array}$} \\
\hline & & $1 \times 10^{-4}$ & $1 \cdot 10^{-\cdot}$ & $1.10^{\circ}$ & $1 \times 10^{-1}$ & $1 \times 10^{-5}$ \\
\hline \multirow[t]{3}{*}{ Imipramine } & $\mathrm{A}$ & 0 & 2.4 & 0 & 44 & 100 \\
\hline & $\mathrm{B}$ & 0 & 0.9 & 1.5 & 15 & 100 \\
\hline & $\mathrm{C}$ & 1.1 & 0 & 0.7 & 28 & 100 \\
\hline \multirow[t]{3}{*}{ Dusipramin } & A & 0 & 0 & 0.5 & 30 & {$[00$} \\
\hline & $B$ & 0 & 1.2 & 0 & 18 & 100 \\
\hline & $\mathrm{C}$ & 0.8 & 0.9 & 1.1 & 44 & 100 \\
\hline \multirow[t]{3}{*}{ Trimeprimine } & $\mathrm{A}$ & 0 & 2.3 & 0 & 48 & 100 \\
\hline & $\mathrm{B}$ & 1.4 & 0 & 0.9 & 16 & 100 \\
\hline & $C$ & 0.7 & 0 & 3.5 & 36 & 100 \\
\hline \multirow[t]{3}{*}{ Amitriptyline } & $\mathrm{A}$ & 0 & 3.4 & 0 & 57 & 100 \\
\hline & $\mathrm{B}$ & 0 & 2.1 & 0 & 14 & 100 \\
\hline & $C$ & 0.2 & 0 & 1.9 & 29 & 100 \\
\hline \multirow[t]{3}{*}{ Noxiptiline } & $A$ & 2.7 & 0 & 1.9 & 0.9 & 68 \\
\hline & B & 1.8 & 1.2 & 0.7 & -14.2 & 29 \\
\hline & $\mathrm{C}$ & 0.6 & 1.5 & 2.1 & $\therefore 9.7$ & 98 \\
\hline
\end{tabular}

Each value represcnts the average of 3 experiments.

noxiptiline) (Table 3) ( $1 \mathrm{~min}$ before the toxic drug, $5 \mathrm{mg} / \mathrm{kg}, \mathrm{i} . \mathrm{v}$ ): a) moderately antagonized the cardiotoxicity in the rat caused by $\mathrm{CaCl}$, (retarding only the onset of ventricular extrasystoles and fibrillation*), cardiotoxicity and lethality in the rat caused by aconitine (retarding the onset of ventricular fibrillation and death time) and in the guinea-pig caused

* Anitriptyline anticipates the onset of ventricular extrasystoles caused by $\mathrm{CaCl}_{\text {. }}$. 
TABly 3 Effects of i.v, perfusions with $C \mathrm{Cl}$. BaCl and aconitine in the rat and with $k$-strophantoside in the guinea-pig. The animals were pre-treated or not for 1 min with differon! drugs.

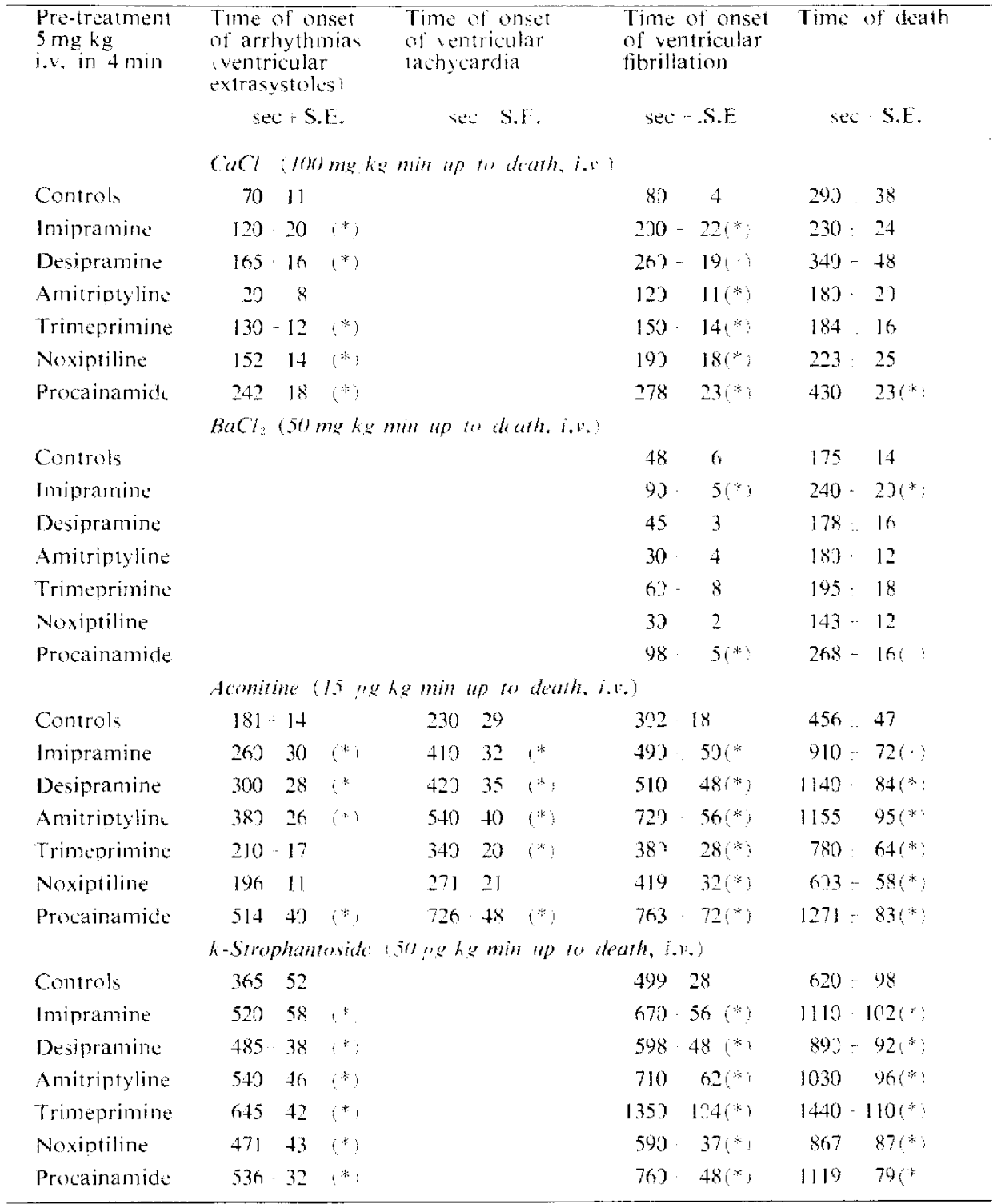

Fach value represents the average of 6 experiments.

(*) Statiscically significant falue calculated as compared to controls ( $P$, 0.05 ).

S.E. standard error.

by k-strophantoside (retarding the onsel of ventricular extrasystoles and fibrillation and deathime. Imipramine, desipramine, amitriptyline and trimeprimino showed an antiarrhythmic activits, very slightly stronger than that of noxiptiline in the case of aconitine and k-strophantoside; by did not modified the cardiotoxicity and lethal effests in the rat. saused by $\mathrm{BaCl}$. (only imipramine moderately retarded the onset of ardiotoxic and lethal 


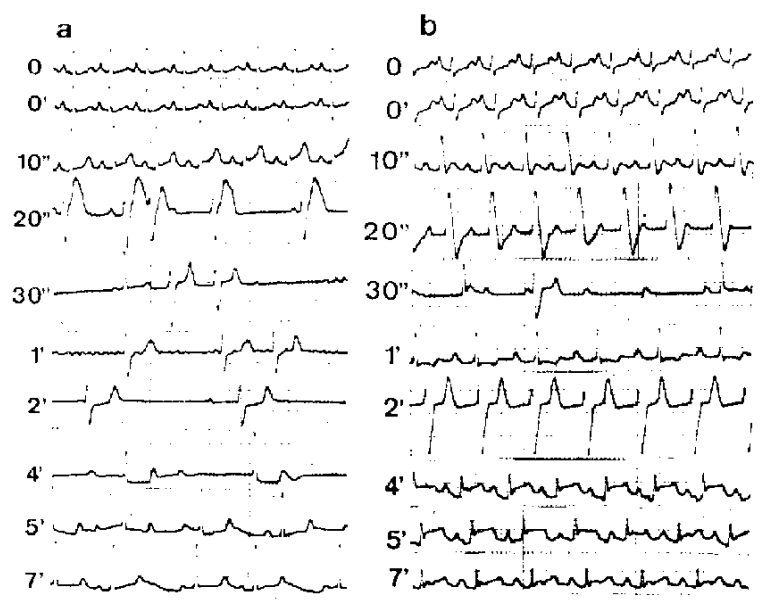

FICi. 9. Effects of pitressin on ECG of guinea-pigs treated for 1 min with $\mathrm{NaCl}$ $0.9 \%$ (a) or with noxiptiline (b). $0^{--}$basal ECG; $0^{\prime}-$ ECG carried out $1 \mathrm{~min}$ from $\mathrm{NaCl}$ (a) or noxiptiline (b). Side numbers indicate times from pitressin.

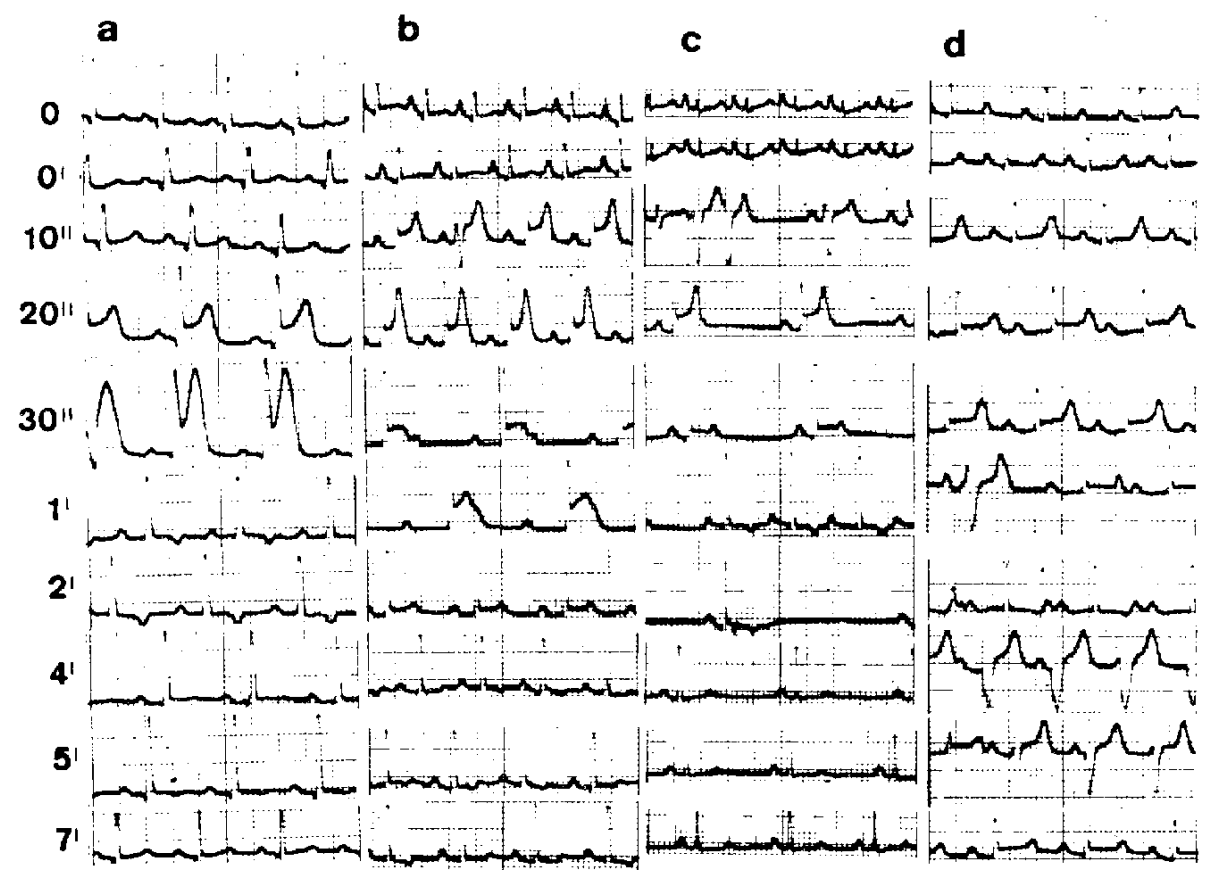

FIG. 10. Effects of pitressin on ECG of guinea-pigs treated for 1 min with amitriptyline (a), with imipramine (b), with desipramine (c) or with trimeprimine (d). 0 - basal $E C G ; 0^{\prime}=E C G$ carried out 1 min from the tricyclic derivatives. Side numbers indicate time from pitressin.

effects); c) do not remarkably modify the ecgraphic signs of coronary spasm (alterations of ST segment; increase in height or inversion of $T$ wave, lengthening of PQ and QT segments) and of rhythm disturbances (sinus bradycardia, ventricular extrasystoles, partial and total 
atrio-ventricular blocks and branch blocks) caused by pitressin in the guinea-pig (Figs. 9, 10). Procainamide (Table 3 ) showed evident anti-arrhytlrmic effects, stronger than those of the tricyclic derivatives with regard to $\mathrm{CaCl}_{2}, \mathrm{BaCl}_{2}$ and aconitine; with regard to $\mathrm{k}$-strophantoside, the anti-arrhythmic activity of procainamide was weaker than that of trimeprimine and equivalentto or slightly stronger than that of imipramine, amitriptyline and that of desipramine respectively.

\section{DISCUSSION}

The tricyclic antidepressives (imipramine, desipramine, amitriptyline, trimeprimine and noxiptilinc) in vitro caused (in adequate concentrations) a negative inotropic and chronotropic effects (with reduction of the coronary flow). In vivo (in adequate doses) caused disturbances of excitability, conduction and of depolarization, qualitatively similar to those observed by other authors in experimental and clinical studies (2-18).

In adequate doses, the 5 tricyclic antidepressives showed a slight anti-arrhythmic activity with regard to k-strophantoside in the guinea-pigs, and to aconitine and $\mathrm{CaCl}_{2}$ in the rats. They did not modify the cardiotoxicity caused by $\mathrm{BaCl}_{2}$ in the rat and by pitressin in the guinea-pigs. The anti-arrhythmic activity which we have recorded for imipramine, desipramine, amitriptyline and trimetpimine with regard to $\mathrm{k}$-strophantoside, $\mathrm{CaCl}_{2}$ and aconitine agrees with the observations made by several authors; i.e. Kosmider and Smolarz (17) for imipramine with regard to digoxine; Fekete and Borsy (7) for imipramine, desipramine, trimeprimine amitriptyline, with regard to $\mathrm{CaCl}_{2}$, aconitine and intracardiac electrical stimulation, and by Schmitt (13) for imipramine with regard to ouabaine, aconitine and adrenaline.

The effects observed on the heart (in vitro and in vivo) and the anti-arrhythmic effects can be ascribed (also considering their local anesthetic activity and other investigations of ours) to a direct action of the drugs on the cell membrane with a reduction of the transmembrane potential and of the active ionic transport at the level of the myocardic celle.

\section{SUMMARY}

The present investigation was carried out for a toxicological experimental study with imipramine, desipramine, amitriptyline, trimeprimine and noxiptiline on ECG and on the isolated heart. The 5 tricyclic antidepressives showed at high doses: a) a decrease in the cardiac inotropism chronotropism, excitability, conduction and depolarization and a decrease in coronary flow; b) a slight anti-arrhythmic activity.

Acknowledgement: Messrs. Bayer for their kind donation of noxiptiline, amitriptyline and trimeprimine and Geigy for their kind donation of imipramine and desipramine.

\section{REFERENCES}

1) Marmo, E., Coscia, L. and Aulisio, G.A.: Angiologica 4, 256 (1967)

2) Baum, Th., Shropsilirf, A.T., Rowles, G. and Gluckman, M.J.: Europ. J. Pharmac. 13, 287 (1971) 
3) Boissier, J.R., Simon, P. and Witchitz, S.: Thérapie 20, 67 (1965)

4) Cairncross, K.D. and Gershon, S.: Med. J. Alust. 2, 372 (1962)

5) Evrelx, J.C.: Effects Cardiaques de l'Imipramine et de sés Dérivés. Masson, Paris (1967)

6) Evreux, J.C., Vincent, V. And Faucon, G.: Proc. Soc. for the Study of Drug Toxicity, 9, 52, Excerpta Med. Foundation (1968)

7) Fekete, M. AND Borsy, J.: Med. exp. 10, 93 (1964)

8) Fotrnier, E., Mellerio, F. and Efthymou, M.L.: Anesth. Analg. Réanim. 23, 263 (1966)

9) Greeff, K. ANd WaGner, J.: Arzneim.-Forsch. 19, 1662 (1969)

10) Lamarcile, M., Roytr, R., Weillfir, M. and Denis, P.: Thérapic 21, 59 (1966)

11) Lechat, P., Auclair, M.C., Fontagne, J. and Prldhommeaux, J.L.: Thírapie 24, 263 (1969)

12) Matsuo, S.: Jap. J. Pharmac. 17, 279 (1967)

13) Schimit, H., Cheymol, G. and GildekT, J.C.: Archs. int. Pharmacodyn. Thér. 184, 158 (1970)

14) Sigg, E.B., Osbornf, M. And Korol, B.: J. Pharmac. exp. Ther. 141, 237 (1963)

15) Alps, B.J., Harry, T.V.A. AND Witson, A. B.: Br. med. J. 3, 743 (1968)

16) Bar.ies, R.J., Kong, S. M. and Wu, R.W.Y.: Br. med. J. 2, 222 (1968)

17) Kosmider, S. and Smolakz, W.: Z. Kreislaufforsch. 57, 1144 (1968)

18) Bismuth, C., Bodin, F., Pebay-Peroula, F. anid Frejaville, J.P.: Press. méd. 76, 2277 (1968) 